\title{
NATIONALIZATION AND INTERNATIONAL PATENT RELATIONS
}

\author{
ERvin O. ANDERSON*
}

I

The object of this essay is to examine the relation between socialist institutions and the patent system. More specifically, we mean to investigate: (a) the position of a citizen-patentee amid socialist institutions; (b) the position of a foreign patentee in petitioning for and holding patents in a nationalized economy; and (c) the significance of a foreign sovereign's acquiring or holding patents in the jurisdiction of another government. Two of these inquiries raise issues of public policy. The United States Government cannot remain unmoved at the prospect of its nationals' property rights in technology being radically affected by the nationalization of industries abroad which are or might be users of such property. Nor can our Government fail to assess the effects upon our domestic trade and commerce of the holding of large blocks of United States patents by foreign governments. A part of the essay which follows will attempt to set forth the steps which our Government has taken to met these problematic situations.

The study ventures upon unfamiliar grounds. Our information concerning the significance of the patent in socialized states is abundant in a country like the Soviet Union, where socialism is not only complete but of sufficient duration to provide generalizations. The case of countries which have recently come to socialism, and then only on a limited scale, is quite different. Here our knowledge is meager, our generalizations hardly more than conjectures, and the challenges engendered by the new institutions have scarcely been discerned, let alone met. There will, therefore, be ample room for correction of fact and emphasis in later studies.

II

Pigou could write with confidence in the third decade of this century that socialism was to be likened to an island in the lake of capitalism. Recent history has not marred the literary elegance of his sentence, for if we invert its meaning it can still express a truth. Most of the world's goods are, to be sure, produced under capitalist institutions, but the majority of European peoples are now living under governments which in varying degrees of intensity can be considered socialist. At the outbreak of World War II the USSR was the only conspicuous socialist economy; but in the short space of a half decade eight countries have in some measure

- A.B. 1936, M.A. I938, University of California; graduate study, University of Chicago, Columbia University, New School for Social Research, 1938-4I. Presently employed in the Division of International Resources, Department of State. The opinions expressed in the article are those of the author and are not necessarily shared by the Department of State. 
adopted socialist institutions. Five countries, Bulgaria, Poland, Hungary, Rumania, and Yugoslavia, are relatively unindustrialized countries where the substance of the new socialism has its greatest significance in land reforms. In two countries the course of socialism has been modest, but because France and England are highly industrialized areas the effects will doubtless be of great consequence. Socialism in Czechoslovakia is not only an industrial phenomenon but far more pervasive than the "socialisms" of western Europe.

The use of the term "socialism" can present considerable difficulties in definition. However, since we are concerned with the more obvious consequences of socialism, we can be content to define it as a form of organization in which a bureaucracy maintained by communal levy undertakes to issue the principal commands with respect to industrial and business policy. In its more familiar form socialism usually includes the passage of title to some or all of the industrial capacity of a country to the government, but where the bureaucratic command is pervasive and detailed "the ownership of the means of production" by the state is little more than an accounting device.

The advent of socialism in western and eastern Europe has left no significant accretions in the patent laws of these countries. The evidence at hand suggests that the juridical and administrative procedures for acquiring and defending patents have not been materially altered. Thus, we are obliged to look beyond the ordinances and rules through which a government grants a patent monopoly to the new institutions cast up by socialism, and inquire how the old patent works in the new milieu.

\section{III}

In a capitalist economy a patent has a legacy of meaning on which most of us can agree. The patent gives a patentee or his designated agent an exclusive right to practice an invention for a prescribed period. In many jurisdictions, where conventional property institutions exist, he is free to refrain from practicing his invention. And once in possession of a monopoly grant the patentee, notwithstanding the metaphysical disputations to the contrary, can treat his grant as "property" and proceed to bargain as he would if he controlled less unusual property. There is no need to enter here upon the many uses which such property is made to serve in a capitalist economy, for the ways of the patent are as manifold as the stratagems of persons and the practices of business enterprise. ${ }^{1}$ But what is important to realize is that the decision belongs to the owner of the patent, and that the state or government does not interfere except in cases where the law has been infringed. ${ }^{2}$ The

\footnotetext{
1 An extensive record of the ways of the patent appears in Proceedings of the Temporary National Economic Committee (1939-1940); Hearings before the Committee on Patents on S. 2303, $A$ Bill to Provide for the Use of Patents in the Interest of National Defense or the Prosecution of the War, and for Other Purposes, 77th Cong., 2d Sess. (1942); and Walton H. Hamilton, Patents and Free ENTERPRISE (TNEC Monograph 3I, 194I).

${ }^{2}$ Infringement of the law in some countries includes failure to use the patent, and might involve as a remedy the licensing of the patent by government command.
} 
patentee may never have access to them, but there are a free labor force, private capital, producers of capital equipment ready to serve private interests, and a body of consumers whose purchases are by and large not rationed. A patentee is not ipso facto foreclosed from exercising discretion over use, sale, and production with respect to his invention. His freedom is not absolute, but neither is freedom an illadvised word to describe his estate.

Now whenever initiative for business and industrial policy shifts to a bureaucracy maintained by a communal levy, and whenever title to a substantial portion of a community's industrial plant passes to government, we have socialism. But it is not the static nature of an economy which arrests our attention; it is rather the government's policy as to how and when new enterprise may be started, and by whom. Socialism usually also implies that government has made known in advance that certain fields of activity are open or closed for private endeavor. Such declarations may be candidly made in laws, regulations ordinances; sometimes, however, policy must be inferred from the hurdles which government puts in the way of the activities of its citizens or residents. ${ }^{3}$

Where government, through bureaucratic control or ownership, or both, makes the vital decisions as to production, sale, source and availability of credit, and labor force, the position of the patentee is accordingly altered. For technology is the neglected fourth in the tetrad of factors of production, and as they go so we should expect technology to go. ${ }^{4}$ If technology does not come under direct government command or dominion along with the other elements of production, there are good reasons for it, as we shall presently see.

The limitation on the right of the patentee to put his invention to work in an enterprise of his own risk is one consequence of a "planned" or socialized economy. If an inventor's contribution falls in a field which government owns or manages he is confined to dealing with the government, and if, as is usual, there are no competitors with the government, his bargaining position is lost. Because he is blocked from entrepreneurial paths the patentee must look to such rewards as the government may give him for the use of his inventions.

The status and prerogatives of the citizen-patentee in a country like the USSR with a long history of socialism are well known. Research and professional invention is a select career and its practitioners enjoy above the average income, housing, food and clothing rations, and educational advantages for their children. The basic reward for contributions to the advancement of the industrial arts is a professional emolument, and the patent or author's certificate is, as it were, a bonus. The provisions of the Soviet patent system are set out in the revised law of $1941,{ }^{b}$ and convey

The hurdles may take many forms: permits for raw materials, permits to produce, quantitative restrictions on production or sale, control or refusal of credits, control of labor force, currency control, taxation schedules, etc.

"Veblen perhaps unjustly berated his fellow economists for neglecting the "state of the industrial arts" as a factor in production. Thorstein Veblen, The Enaineers and the Price System 27-28 (1921).

Sobraine Postanovlenii i Rasporiazhenii Pravitelstva Soyuza Sovetskikh Sotsialisticheskikh Respublik, March 25, 1941, No. 9, Art. 150. The Legal Division of the Library of Congress has translated the entire law. 
to the first and true inventor a fifteen-year monopoly on his invention. The patentee is free to license any individual or corporation in the USSR, and has the customary relief against the unauthorized use of his invention. The law provides that in the event the patentee and a prospective licensee fail to reach an agreement as to the conditions of use of a patent, the state may declare a compulsory license. No special awards or rewards are given the patentee beyond the terms he reaches in an "open" bargain with his licensee. Any foreigner may secure a patent in the USSR on the same conditions as a Soviet national.

The author's certificate, which is a distinct departure from the conventional patent, has a wide currency in the USSR. The certificate testifies to the novelty of the invention and names the person responsible for the contribution. All rights and title to the invention pass upon issuance of the certificate to the state, and the inventor receives a compensation adjusted to the contribution of the invention to efficiency, improved quality, and sales of a new product. ${ }^{6}$ In addition to monetary rewards, certain social benefits run to the inventor. Unlike the patent, the author's certificate does not require the payment of annual fees for its maintenance. The Soviet policy of favoring the author's certificate over patents has borne fruit; Soviet statistics as of 1935 show that under the 193 I law 99 per cent of all domestically developed patentable inventions were covered by author's certificates.

Under Soviet practice the patent is a vestigial institution; it is suffered principally in order to give the appearance of a regime of equality for inventions of foreign origin.

The systems of privileges and rewards for inventors and research workers employed in nationalized industries in countries newly come to socialism have their origins in the past. It is clear that the advances in technology in nationalized industry will be made by government personnel, and governments have merely extended their traditional policy toward the inventions of their employees to research workers employed in nationalized industries. The rules generally provide that if the employee is hired to do research, all rights pass to the government; and where invention results during the working hours of the employee or is assisted by knowledge and facilities provided by government, certain equities in the invention are to pass to the government. As a rule (which present circumstances tend to render inflexible) the employee is obliged to pass foreign rights to the government. ${ }^{8}$ As government begins to assume the entire burden for the progress of the industrial arts in nationalized fields, rather than the role of partnership with private enterprise which was customary in western Europe in pre-World War II days, it is likely that

\footnotetext{
- Decree of the Soviet of People's Commissars of the USSR, No. 1904, Nov. 27, 1942, Concerning the Confirmation of the Directive Regarding Remuneration for Inventions, Technical Improvements, and Suggestions for Rationalization, sets forth a detailed schedule for rewards for inventions covered by author's certificates. Available in translation at the Library of Congress.

I7 J. PAT. OfF. Soc'y 572 (1935).

8 See Report and Recompandations of the Attorney General to the President, Investigation of Governarent Patent Practices and Policies, Vol. III (Gt. Britain) 85-rog, (France) iog-imi (1947). Substantially the same practice exists in Czechoslovakia, Poland, Hungary and Rumania.
} 
a more formalized arrangement will have to be achieved. For government now enjoys a monopoly in the nationalized fields, and for the employee to retain even limited rights to inventions in the hope of attracting additional rewards is no longer possible. His only customer is his employer.

The change in the status of the patentee has been accompanied by the assertion of a direct interest by the government in patents. Nationalization has led to the passage of title to patents from private enterprises to government, and in a manner of speaking government has recovered its own monopolies. Some violence has been done to the traditional conception of the patent when government undertakes to grant to itself patent monopolies. For it is universally recognized that the patent, is given by governments for an advance in the useful arts, and where the government is the patron and source of the advance it is in the curious position of rewarding itself. True, the actual agent of invention is the government employee, but the conveyance of a patent to him, only to take it away as a condition of employment, is a cumbersome way of recording and recognizing technical achievement. If reason rather than custom informs this action, the government's practice must be directed to outsiders and not its own nationals. A patent duly protecting an invention may enable a government to proceeed with production, use, and sale of the invention without embarrassment from rival claims made by foreign nationals in its own patent office. Likewise, control of patents gives a government a measure of control over foreign investment and imports through a device which in appearance is far less arbitrary than quantitative restrictions on imports, tariffs, embargoes, currency controls, and similar devices. Doubtless the maintenance of a domestic patent system also provides a medium through which technology of foreign origin may come to the country and find general disclosure. And finally, despite the de facto inequalities in socialist and capitalist economies as to the right to exploit patents, the maintenance of a patent system and patent office at least suggests a format equality between the two regimes.

\section{IV}

One of the larger consequences of nationalization for international patent relationships is the passage of patent rights in foreign jurisdictions from their nationals to the nationalizing governments. There can be little doubt that the scope of recent nationalization decrees in Britain, Czechoslovakia, Hungary, Rumania, Yugoslavia, France, and Poland, among others, has vested in the governments full title to and administrative powers over foreign patents controlled by their nationals. ${ }^{0}$ It requires little reflection to measure the consequences. One government hereafter will exercise in the jurisdiction of another government some powers over the domestic trade and manufacture of the latter. The extent of such powers, moreover, will be more than nominal, for most nationalizing governments have inherited entire industries together with the whole repertoire of technology peculiar to those industries. And

'The areas nationalized differ in the countries enumerated, but this does not alter the pattern of control over those sectors of the economy that have been nationalized. 
because the repertoire of technology, at least as to its strategic elements, has doubtless been subject to patents in foreign jurisdictions, the nationalizing government is in a position to interfere substantially in the economic life of other countries. As we shall see, this situation is likely to be aggravated when future technology originating with governments with nationalized industries or governments supporting large-scale research endeavors with public funds seek and acquire patents in foreign jurisdictions.

The ownership of patents by one sovereign in the territory of another sovereign is strictly a contemporary phenomenon. ${ }^{10}$ But there are signs at hand to indicate the uses to which the patents are to be put. One government in dire need of dollar exchange is pursuing the policy of licensing its patents to American manufacturers, usually on an exclusive basis. Such practice is tempered by export policy; licenses will not be forthcoming when in the opinion of the government it can more remuneratively service the United States market with its own manufactures. Of the countries newly come to socialism in some degree, France, Great Britain, and Czechoslovakia have a vital interest in the United States market, and it may be expected that self-interest will dictate that their position be used to secure a place in this market. It is unlikely that these governments will take up their right to manufacture in the United States; but advantage and power may cause them to withhold their technology from domestic manufacturers. ${ }^{11}$

The patent position of foreign governments will not be completely accounted for by the research activities of their nationalized industries. It has long been recognized that research of a basic and applied nature is a proper function of government, and the postwar budgets of the major countries reflect the fact that government will play an increasingly active role in subsidizing and sponsoring industrial research. A considerable literature exists on the organization and direction of government research in foreign countries; here it suffices to record that Great Britain is spending 19.5 million pounds annually on civilian research, ${ }^{12}$ France 917.8 million francs. ${ }^{13}$ But the chief point to be made for our purposes is that the research is preponderantly in the field of applied science, capable of yielding patentable inventions, and that the problems pursued reflect the government's interest in improving its competitive position in foreign markets. Patents, both domestic and foreign, will therefore emerge from these "public interest" activities in greater numbers than from the research associated with nationalized industries.

The exercise of wide powers by one sovereign over commerce and industry in the

\footnotetext{
${ }^{10}$ The older socialism of the USSR has paid little attention to foreign patents. In the United States some twenty patents were issued to nationals of the USSR in the period 1940-46. See 29 J. PAT. OFF. Soc'y 102 (1947). There is no current knowledge at hand to show how these patents have been administered, but they fall in widely diverse fields and have not exercised any appreciable influence on industry in the United States.

${ }^{11} \mathrm{I}_{\mathrm{t}}$ is well known that there are no existing powers at the disposal of this government to compel the licensing of domestic manufacturers.

12 I59 NATURE 702-3 (1947).

13 Budget of the Government of France (1947).
} 
'territory of another sovereign is something which western mores, sometimes called international law, do not condone. It is not necessary to document the fact that an allegation that such powers have been exercised is subordinate in gravity only to the charge that the territorial sovereignty of a government has been violated. Indeed, the proliferation of international organizations under the old League and now under the United Nations is fundamentally designed to insure agreed and concerted action between states toward common problems, so that no government will be obliged to bear the onus of having interfered in the domestic affairs of another country by unilateral action. ${ }^{14}$

There is a temptation to resolve the public policy issues of a government's exercising direct influence over the economy of another state by recourse to a kind of formal reasoning based on the principles of "national treatment" or "reciprocal treatment."15 Thus, in the first case it could be said that this government should not take any special action against the patents or applications for patents of foreign governments, on the ground that our government also takes out patents, and that equality dictates similar treatment. The principle of reciprocity might be used to argue that since no foreign government formally discriminates against United States Government-owned patents, the United States should offer formal safeguards for inventions originating with foreign governments. Doubtless, both principles circumscribe what constitutes equity in dealing among nations, and for this reason we have no quarrel with them. But we do maintain that into the formalisms there needs to be interjected a liveliness born of facing the de facto situation squarely; the principles are guideposts to a solution, they are not resolutions of the problem.

The bare fact of a sovereign's holding United States patents is of little consequence. The situation becomes problematic only when the patents are used in a manner to further the economic welfare of one country at the expense of another. And this means among other things deciding that the country granting the patent is to be an importing territory, and that the patentee-government will block production in the country conveying the patent by refusing to license nationals of that country. We have seen that this is more than a contingency to be entertained in theory.

Now to be sure, a patent policy such as that just outlined can be pursued with impunity by a citizen patentee of a foreign country. But a citizen, and here I do not mean a patentee who comes to our patent office in his own name as a servitor of his government, cannot be accused of political motives, whereas these are precisely the antecedents of government acts. And no remonstrances will serve to dispel this impression. The principle of "national treatment," therefore, proclaims an inequality when it says that a politically minded sovereign petitioning for a patent should be

\footnotetext{
${ }^{14}$ The International Bank and the proposed International Trade Organization are examples.

${ }^{15}$ National treatment: treatment on a par with that extended to nationals of a state. Reciprocal treatment: treatment afforded to an alien on the basis of the treatment extended by the state of which the alien is a national to nationals of the receiving state.
} 
on the same footing as a national of the home country. And even when the principle counsels the equal rights of a home government and a foreign government in a patent office it fails to enforce strict equity because it has been the traditional policy of the United States Government to license all applicants under United States Government-owned patents on a royalty-free basis. This, needless to say, is a policy not pursued by any foreign sovereign under its United States patents.

The invocation of the principle of reciprocal treatment is also beset with diffculties. For while foreign sovereigns may use their United States patents to make the United States market a preserve for certain kinds of manufactures, the United States Government, standing on an equal footing with other patentees of foreign countries, is for the same acts that foreign countries commit in the United States liable to "licenses of right" and other varieties of compulsory licensing. Moreover, if the United States Government's patents fall in the fields of nationalized industry, its bargaining position, compared with that of foreign sovereigns who have a multitude of competing firms to.approach in the United States, is severely limited.

From the foregoing it becomes clear that a solution is not available if attention is limited to considerations of formal equalities. Where institutions and policy in different countries vary widely, formal equivalences are fraught with travesty. Faced with this dilemma, some might advocate the abolition of the problem by recommending the revocation of existing government-owned patents, putting a stop to the issuance of patents to governments, or possibly enacting compulsory licensing legislation to run against governments.

Such proposals are extreme. Proponents of such views have probably not reflected on the fact that in many countries the combination of nationalization and government support of research will result in all technology's having its origin with the government. Under these proposals the technology of such a country could not be protected in the United States. On the other hand, American technology, which originates both with government and with private agents, can at this time find protection in foreign patent offices. Such a regime of inequality could not be long condoned by the affected foreign governments. The retaliation which foreign governments would direct against the United States would in all probability embrace both government and private technology; for the foreign government would look to the substance rather than the form of the American discrimination. If the United States refused to protect the patentable technology of another government, where that technology was wholly accounted for by the government's activities, that government would feel justified in excluding the entire repertoire of American technology from the privileges afforded by its law.

\section{$\mathrm{V}$}

An Executive Order recently released represents the attempt of this Government to arrive at an equitable solution of the problem of a foreign sovereign's exercising monopolistic rights in the form of patents in the territory of another sovereign..$^{10}$

\footnotetext{
${ }^{16}$ Exec. ORDer No. 9865, June 14 , 1947, providing for the protection abroad of inventions resulting from research financed by the Government.
} 
The order requires agencies of this Government to "acquire the right to file foreign patent applications on inventions resulting from research conducted or financed by the Government." The order clearly envisages that the United States Government will grant licenses on a non-exclusive, royalty-free basis to United States nationals and that such patents shall serve to assure a non-exclusive right to American nationals to exploit foreign markets. Paragraph 5 of the order cites further general powers whereby the Department of State, in consultation with the Department of Commerce, is authorized to enter into an exchange of patent rights with foreign governments.

While no information has been publicly released to clarify several of the dark passages of the Executive Order, it is possible to infer the regime envisaged by the order.

First, the order does not impair the rights of foreign governments to acquire patents in the United States. And because the directive requires that United States Government agencies are to pursue a policy of acquiring patents in foreign jurisdictions, it may be assumed that this Government does not intend to take any action at this time which would cause foreign governments on their part to contest this Government's presence in their patent offices.

Second, the preamble to the order, which declares that "it is in the interest of the Government to foster, promote, and develop the foreign commerce of the United States," establishes the fact that this Government regards it to be a fair and equitable policy for governments to attempt to provide access for their nationals to foreign markets through the control of patents.

But third, the offer of this Government to exchange rights to foreign patents with other governments (Section 5) implies that this Government, under appropriate circumstances, is willing to forego exclusive rights under its foreign patents on condition that other governments are willing to do the same with respect to their foreign patents. Notice has already been taken of the fact that among the purposes of the order is the stimulation and promotion of the foreign commerce of the United States, and to this end non-exclusive, royalty-free rights to United States Government foreign patents will pass to American nationals. Thus it would appear that it is the intention of the United States Government to pass only limited rights to foreign governments under a patent interchange agreement, reserving for itself the right to sublicense its own nationals under such patents and thus insuring access by American nationals to foreign markets.

The implication of this Order is clearly that sovereign governments should establish a regime of equality by agreeing with one another as to the conditions of use of their patents. Such a course would render unnecessary radical measures such as closing patent offices to governments, or in the case of the United States, instituting a compulsory license system directed against the patents of foreign governments. More important, an accord on the use of patents would dispel the impression that a government was using its patents to further its own economic and political welfare 
at the expense of the government granting the monopoly. The ugly surmises that a government was restricting manufacture, inhibiting research, or plotting an exclusive sales territory could be dismissed as the extravagant claims of the irresponsible. If governments agreed on licensing provisions with respect to their foreign patents they could clearly reserve for themselves the right to assure the access of their own nationals to foreign markets, which, upon reflection, may be the only legitimate reason for governments' taking patents in foreign jurisdictions.

To be sure, a multilateral or bilateral pooling of governmentally owned or controlled foreign patents involves renunciation; not to be able to convey exclusive rights under patents to their nationals or, alternatively, to others for a monetary or other consideration is to give up rights to which the patentee is formally entitled under the monopoly. But with the renunciation there are rewards. The first benefit is that each signatory government will be assured that the patents granted to foreign sovereigns will not be used to interfere with its domestic economy; an allied advantage is that each government in opening its patent office to the inventions of a signatory government will be assured that its nationals will be free to exploit such inventions. And the entire construction sustains in a practical way the usefulness of the patent institution as a means for the interchange of the industrial arts and protects the system from the corrosive effects of political attack which is sure to come if sovereigns cannot satisfactorily separate their economic and political roles.

VI

The effect of the trend toward socialism that has taken place since the conclusion of the war in Europe upon the position of the foreign patentee has provoked little comment from students or beneficiaries of the patent system. ${ }^{17}$ The hesitation may be born of prudence, for no definitive assessment of the effects can as yet be had. None the less, it is significant that in two recent conferences on international patent relationships $^{18}$ no intimation of question arose as to the position of the foreign patentee with inventions falling into the operating domain of a nationalized industry. Governments and patent agents have been concerned with mending the fences of the patent system; insuring at the Neuchatel Conference a common policy with respect to the effect of war on acquiring and maintaining patents; and exploring at The Hague certain procedural modifications in the Convention for the Protection of Industrial Property. These valuable international performances tend to reinforce the conviction that international agreement on patents is as yet confined to formal equivalences in treatment.

While governments and patent agents may delay their response to the new situation, business enterprises, which produce crops of inventions as a byproduct of

${ }^{27}$ A good analysis of this problem has been made by Robert P. Terrill, Cartels and the International Exchange of Technology, 36 AM. Econ. REv. 745, 76I-767 (1946).

${ }^{18}$ Recent meetings have been held by the International Association for the Protection of Industrial Property, May 26-3I, 1947, at The Hague; and the Union for the Protection of Industrial Property, Feb. 8 , 1947 , at Neuchatel. 
organized research, must decide without delay where they are to seek protection for their inventions. And the decision as to where they will seek protection involves an evaluation of where and under what conditions they can do business.

Although the sample is not large enough to yield firm generalizations, the writer has inquired of a half dozen of our largest American corporations, ${ }^{10}$ which habitually took patents and conducted business in Europe before the war, what changes, if any, the new circumstances have made in their patent policy. They report that they are applying for patents on their inventions in countries like France and England, notwithstanding effective or proposed nationalization in fields of their interest, on the assumption that these governments will bargain in the customary manner for access to technology of foreign origin. The expectation is that those charged with the direction of nationalized industry will carry on patent relationships with the American firms in about the same manner as they were carried on by the former private owners.

American companies actively interested in eastern Europe, excluding the USSR, are continuing to file applications for patents in approximately the same volume that they did prior to the war. The reason for taking patents in such territories appears to be based on their policy of safeguarding exports to these territories and the desire to lay a basis in patents for future technical cooperation with the governments involved. In the case of those companies which are applying for patents in order to assure entrance for their exports, there is a conviction that industrial development in the more complex fields will probably be slow in its realization and that for a considerable period of time these countries, in certain complex and specialized fields at any rate, will be dependent on foreign suppliers.

Those companies which are filing applications for patents in eastern Europe in anticipation of technical aid agreements believe that a firm patent position in a country may lead the foreign government to select them rather than a competitor for a technical aid agreement. The firms also reason that in the event that they are not selected as the company to execute a technical aid arrangement they will be in a position to exact royalties in the event that their inventions are used.

The extent of patent protection sought differs according to the industry in which the companies are involved and their traditional interest in the eastern European markets. Almost no applications for patents are being submitted in Yugoslavia, but what are regarded as fundamental inventions are being reduced to patents in Hungary, Rumania, and Poland, while in Czechoslovakia almost the entire repertoire of inventions normally protected in western Europe is subject to patents.

All of the companies interviewed confirm evidence from other sources that they do not take patents in the USSR except when explicitly requested to do so, pursuant to a technical aid contract with a Commissariat. ${ }^{20}$ As we have already intimated,

${ }^{20}$ The companies involved have generously allowed their policies to be discussed, but for obvious reasons do not wish to have their identities disclosed.

${ }^{\circ}$ The number of patents taken out by Americans in the USSR in the period r93r-1934, the last period for which information exists, does not exceed 155 . The figures are accepted by the United States Goverament. 
patent relationships between this country, its nationals, and the Soviet Union are so few and so fugitive as to make it unnecessary to take up the position of the USSR in the live questions under discussion. The fact that there are not better technological relationships between the two countries should be investigated, but this problem is outside the confines of this paper.

By and large, American nationals are behaving in socialist countries as if governments will negotiate in a normal commercial manner for rights to their patented technology. And there is much to support their optimism. For some years to come, at any rate, the United States will be the principal source for improved industrial technology if only because of the volume of expenditure by government and business for research. The principal source for capital equipment in which such improvements will be incorporated will also be the United States. A government which adopted a policy of confiscating inventions of American origin, or which made frequent or arbitrary use of its compulsory licensing powers, would scarcely invite the confidence which it might require in order to put its industrial plant on a modern basis. Disregard of private foreign rights in inventions would, of course, not mean that the inventions were free to be used. The use of patents requires two assents: the assent not to sue the user, and the assent to pass on the know-how. "The latter consent implies a peculiarly sympathetic relationship which does not thrive in an atmosphere of fiat or coercion.

Now if a government failed to treat patents according to the canons normally surrounding private property, the consequence would be that foreigners would not apply for patents in that country. This would not necessarily spell the termination of technological relations between the foreigner and the government. Technology often is, and in this case could be, taken out of the legal arena entirely, and instead of bargaining with the patent in the foreground, the transaction would involve the invention, its mode of manufacture, and the all important know-how. Under these circumstances the foreigner would drive a hard bargain; instead of a normal royalty return to run for the life of his monopoly, his price would be calculated on the basis of some estimated maximum use of his invention designed to recoup for the absolute loss of his invention. A government comparing the price asked with a royalty arrangement in effect in some other country would quickly discern the price of a no-patent policy. Indeed, some students have suggested that some Commissariat of the USSR perform such a calculation in the interest of estimating the cost of that country's ineffective patent protection for foreigners.

But, of the various factors tending to reenforce the expectation that governments with nationalized industry will deal fairly with the industrial property of foreigners, none is more relevant than the observation that these countries still in some measure maintain capitalist institutions. The extent of socialist enterprise varies in countries like Great Britain, France, Poland, Czechoslovakia, Rumania, and Hungary, but in 
all of these countries there is present a sizable region of private ownership and, therefore, a recognized limitation on the principles of socialism. There are patents held by nationals of socialist states which the government recognizes as private property, and such practice may provide the crucial exception which may be applied to the patents of foreign nationals.

It would be foolhardy, however, to suppose that even compelling reasons for amicable patent relationships between socialist and capitalist states will necessarily cause them to take place. The importance of such relationships may be mutually recognized, but the larger political questions which divide eastern Europe from western Europe and the Americas may provide barriers to the movement of men, goods, and knowledge, to the disadvantage of all concerned. But prognostication on such issues goes beyond the bounds of this essay.

So far we have conjectured about the effect of nationalization on future patent rights held by foreigners. What effects has nationalization had on patents already issued to foreign nationals? It is obvious that at least three categories of patent rights are involved: (I) patents held by corporations in which American nationals enjoy stock participation; (2) patents owned by American nationals which have been licensed to a person or corporation doing business in the country; and (3) patents owned outright by an American national which have not been licensed.

The effect of nationalization on existing patent rights is confined to eastern Europe, including Czechoslovakia. The limited nationalization plans in France and Great Britain have not affected the titles of American nationals to their issued patents.

Corporations in which Americans have a substantial stock interest have been nationalized along with all assets in the form of patents by the governments of Rumania, Czechoslovakia, Poland, and Hungary. In a number of cases the nationalized corporation was held by American nationals through the medium of a German-domiciled corporation, and this has given rise to a range of controversy turning on the question whether the seizure constituted an act directed against "enemy" property or, in fact, involved the confiscation of private property owned by American nationals.

In a number of cases corporations nationalized by eastern European governments have been iicensees under patents owned by Americans in the local jurisdiction. The laws and ordinances pursuant to which confiscation took place leave little doubt that the government has assumed control over the licenses, but there is no evidence that the seizure runs to the patent itself. ${ }^{21}$

As far as is known to this writer, patents owned by American nationals which had not been licensed at the time of nationalization have not been affected by socialization legislation.

The public policy issues which face our government as a result of the nationali-

${ }^{21}$ Mention should also be made of a sizable group of American-owned patents in castern Europe which were licensed or assigned to German corporations doing business in eastern Europe. These patents have as a rule been seized by local custodians of enemy property. 
zation of American property in general and patents in particular are confounded by the alleged presence of "enemy interests" in the properties. To this phase of the issue this paper can make no contribution, since it is a matter still under negotiation with the governments involved. Policy is clear, however, when there is agreement between the governments that the property nationalized contains a bona fide American interest. The position of our State Department has been to request adequate and effective compensation for the confiscated property, and such an obligation is typically acknowledged by the nationalizing government in its enabling legislation. It may be anticipated that there will be protracted discussions of what constitutes "adequate compensation," in what medium the compensation shall be paid, and so on.

Such policy fits the circumstance where the American patent is an asset of an American-owned corporation. What of the situation where a license under an American-owned patent, once enjoyed by a private corporation, has now passed to a government? Here equity may be served by allowing the license agreement to proceed under its old terms. But such continuance will be feasible only in the case of the simplest royalty arrangements; if, as often happens, the passage of rights to patents is contingent upon reciprocal access to the licensee's existing and even future technology, there is no way out except closure of the contract for a monetary settlement.

\section{VII}

The persistence of the patent system amid cataclysmic shifts in our economic system -in our own time the advent of nationalization-testifies to the hardiness of the institution. The letters patent emerged in the fifteenth century; the device survived the latter days of feudalism and merged with the objectives of the economy which we designate as mercantilism. Within this system, which persisted from the sixteenth to the middle of the eighteenth century, letters patent served as a visa for alien crafts and craftsmen in their journeys into the would-be self-sufficient Realm. With modification but with unchanged essence, the patent, which under mercantilism served as an instrument of autarchy, became an enabling franchise for vendors in the free-trade economy which characterized the period from the latter half of the eighteenth century to the beginning of World War I. The neo-mercantilism which marked the period between the two world wars has not diminished the vigor of the patent system. Now with the advent of socialism we observe another phase in its career. Perhaps some day a student will write of the resiliency of the patent institution. ${ }^{22}$

22 Dr. Heinrich Kronstein in this symposium has made an important contribution to the history of the patent system in relation to wider economic events. But there is room for more ground-breaking. 